University of Northern lowa

UNI ScholarWorks

4-1994

\title{
Predicting Evolutionary Consequences of Greater Reproductive Effort in Tripsacum Dactyloides, a Perennial Grass
}

\author{
Laura L. Jackson \\ University of Northern lowa \\ Chester L. Dewald \\ Southern Plains Range Research Station
}

Let us know how access to this document benefits you

Copyright (C1994 Ecological Society of American, "Copyright by the Ecological Society of America." The copyright holder has granted permission for posting.

Follow this and additional works at: https://scholarworks.uni.edu/bio_facpub

Part of the Biology Commons, and the Plant Sciences Commons

\section{Recommended Citation \\ Jackson, Laura L. and Dewald, Chester L., "Predicting Evolutionary Consequences of Greater Reproductive Effort in Tripsacum Dactyloides, a Perennial Grass" (1994). Faculty Publications. 1. \\ https://scholarworks.uni.edu/bio_facpub/1}

This Article is brought to you for free and open access by the Faculty Work at UNI ScholarWorks. It has been accepted for inclusion in Faculty Publications by an authorized administrator of UNI ScholarWorks. For more information, please contact scholarworks@uni.edu. 


\title{
PREDICTING EVOLUTIONARY CONSEQUENCES OF GREATER REPRODUCTIVE EFFORT IN TRIPSACUM DACTYLOIDES, A PERENNIAL GRASS ${ }^{1}$
}

\author{
LAURA L. JACKSON ${ }^{2}$ \\ Section of Ecology and Systematics, Cornell University, Ithaca, New York 14853 USA \\ Chester L. Dewald \\ USDA-ARS, Southern Plains Range Research Station, 2000 18th Street, Woodward, Oklahoma 73801 USA
}

\begin{abstract}
To test the prediction that a mutation causing greater reproductive effort will result in reduced vegetative vigor, we compared the seed production, growth, and carbohydrate status of normal and pistillate genotypes of the grass Tripsacum dactyloides differing in seed production by up to fourfold. We evaluated the costs of reproduction by two methods: experimental manipulation of reproductive effort and comparison of highand low-yielding genotypes. Despite the large difference in seed production, normal and pistillate (high-yielding) genotypes did not differ in growth rate over a 1-yr period. Contrary to predictions, carbohydrate reserves in the high-yielding genotype were significantly higher at the peak of the seed ripening period. Stalk defoliation and complete removal of seed stalks reduced plant growth rate, total aboveground biomass, and biomass of vegetative storage organs, especially when plants were also under stress from biweekly defoliation. However, stalk removal caused increased rates of growth in the year after experimental manipulations. Reproductive tillers were costly to the plant in terms of lost meristems and therefore future plant size, but seed costs were contained within reproductive tillers of both genotypes, explaining the lack of a trade-off in the high-yielding, pistillate genotype. Although experimental reduction of reproductive effort revealed a cost of reproduction, this result could not be used to correctly predict the consequences of a gene for greater seed production.
\end{abstract}

Key words: $C_{4}$ grass; defoliation; Eastern gamagrass; life history; Oklahoma; perennial grass; reproductive cost; reproductive effort; seed yield components; tiller dynamics; Tripsacum dactyloides.

\section{INTRODUCTION}

Life history theory has focused on interpreting the patterns of reproduction and growth found in nature. However, successful theory should also be able to predict evolutionary change in response to novel selective forces, novel genetic variation, or both. For instance, life history theory could be used to predict the effects of selection for greater seed yield on a useful plant or the effects of a bioengineered gene affecting growth rate on age of first reproduction or seed size.

The organizing principle of life history theory is that growth and reproduction compete for the same pool of limited resources and that selection will maximize lifetime reproductive success (Cole 1954, Gadgil and Bossert 1970, Charnov 1982). Studies of plant life history evolution have concentrated on measuring the consequences of reproduction in terms of growth and risk of mortality, using two general approaches: descriptions of carbon and nutrient distribution to vegetative and reproductive structures (allocation) and

\footnotetext{
${ }^{1}$ Manuscript received 13 January 1993; revised 3 June 1993; accepted 15 July 1993.

${ }^{2}$ Present address: Department of Biology, University of Northern Iowa, Cedar Falls, Iowa 50614 USA.
}

measurement of the demographic effects of different levels of reproductive effort, brought about by naturally occurring variation or by experimental manipulation.

Harper and Ogden (1970) were the first to suggest that resource distribution reflects the evolutionary priorities of a plant species and that measures of plant biomass might accurately describe these priorities. However, resources other than energy may be limiting (e.g., Hickman and Pitelka 1975, Thompson and Stewart 1981, Abrahamson and Caswell 1982). Even when energy is limiting, part of a plant's energy requirements for reproduction may be met by higher rates of photosynthesis in nearby leaves, or by reproductive structures themselves (e.g., Hole and Scott 1983, Watson and Casper 1984, Tissue and Nobel 1990). These observations led to rejection of resource distribution as a straightforward metric of life history strategy.

The second approach to measuring reproductive costs has focused on the demographic consequences of reproduction (Sohn and Policansky 1977). Several studies took advantage of natural experiments, comparing, for example, the vegetative growth of masting vs. nonmasting trees (Harper 1977:654) and fruiting vs. nonfruiting individuals (Onwekwelu and Harper 1979, Gross and Soule 1981, Policansky 1981, Sakai and 
Burris 1985, Lovett Doust and Lovett Doust 1987). More recently, seed production was experimentally enhanced and/or reduced, and then mortality, growth rate, and fecundity in the current and following year were measured (e.g., Horvitz and Schemske 1988, Lubbers and Lechowicz 1989, Snow and Whigham 1989, Ackerman and Montalvo 1990, Primack and Hall 1990, Fox and Stevens 1991). Many of these comparative and manipulative studies found that plants became smaller during or in the year following high fruit set, reproduced less copiously in the following year, or retreated to a male or nonflowering condition. This was interpreted as a demonstration of the cost of reproduction.

It is not clear, however, to what extent phenotypic variation in reproduction, whether naturally occurring or experimentally induced, is useful in predicting life history evolution (Reznick 1985). A plant's response to experimental manipulation reveals the current nature of the interaction between its system of morphological development and the resources needed for reproduction. Inherited differences among plants may reflect a different interaction between development and resources. In order to predict life history evolution, we need to know what kind of genetic variation in life history traits exists, what developmental changes are responsible, and how those or correlated developmental changes affect other life history traits. Law (1979) found negative genetic correlations between the age of first reproduction and plant longevity in the short-lived perennial Poa annua, but his experiments were not designed to reveal the developmental mechanism behind the trade-off.

In this paper we examine the seed production, growth, and carbohydrate storage of two forms of the longlived perennial bunchgrass Tripsacum dactyloides $\mathrm{L}$. (Dewald and Dayton 1982). Individuals producing 34 times the seed mass of normal plants are found sporadically in wild populations, in very low frequencies, and inheritance of the trait is recessive, at a single locus (Dewald et al. 1987). The goals of the study are to determine (a) whether the high seed yielding, "pistillate" type exhibits a "trade-off" in vegetative vigor; (b) whether experimentally manipulating reproduction has the same outcome as comparing two types that differ genetically in reproductive effort, and (c) whether the costs of producing seeds are strongly coupled to or buffered from the vegetative activities of normal and high-yielding plants. This study differs from manipulative studies of reproductive effort by comparing genetic differences in reproductive effort with experimentally manipulated differences in reproductive effort.

\section{MATERIALS AND METHODS}

Tripsacum dactyloides (L.), or gamagrass, is a large (to $>2 \mathrm{~m}$ tall, $1.5 \mathrm{~m}$ diameter clumps) $\mathrm{C}_{4}$ bunchgrass related to maize found in the southeast and southern plains of the United States (Gould and Shaw 1983).
Potential longevity is unknown, but one isolated plant in Woodward, Oklahoma has been noted for its large size since the early 1940 s.

Gamagrass grows as a population of connected, monocarpic shoots (tillers), which remain vegetative in the season they are initiated and typically become reproductive in the second or third season of growth, apparently after achieving some minimum size (Dewald and Louthan 1979). Vegetative tillers continually produce new leaves and may produce new tillers from axillary buds, but once a meristem undergoes floral initiation, leaf and axillary bud production ceases and the reproductive tiller dies after fruiting. Carbohydrate storage occurs in belowground and ground level stems (proaxes), and the first 3-5 cm of leaf sheaths above each meristem (Williams 1964, Ryle and Powell 1975, Smith 1975, Dewald and Sims 1981). We refer to this region as the "tiller base." Carbohydrate reserve concentrations are highest in the winter and decline rapidly during shoot emergence in the spring. Carbohydrate concentrations reach minimum $\approx 20 \mathrm{~d}$ later, when formerly vegetative tillers "bolt" to $>1 \mathrm{~m}$ height in $14 \mathrm{~d}$, creating reproductive stalks (Jackson 1990). During and after flowering, concentrations of carbohydrates increase until the plants become dormant in early October (Dewald and Sims 1981).

Flowering stalks initiate primarily during $3 \mathrm{wk}$ in May, but a few emerge throughout the growing season. Within a stalk, one "terminal" inflorescence emerges as the stalk elongates, and 10-14 d later, 1-4 "lateral" inflorescences are borne at axillary nodes. Seeds mature 4 wk after fertilization (C. Dewald, unpublished data). Thus, each plant is a multiaged population of reproductive stalks, each with 1-5 inflorescences in two stages of maturity (Jackson 1990).

\section{Plant materials}

A novel form of $T$. dactyloides was discovered in 1981 in a nursery planted from field-collected seed at the United States Department of Agriculture Plant Materials Center in Manhattan, Kansas, USA. In the novel, "pistillate" form, most normally staminate florets are either pistillate or perfect (Fig. 1); seed number is potentially $10-25$ times greater and pollen production is $1-2 \%$ of normal. Inheritance of the pistillate trait is simple and recessive (Dewald and Dayton 1982, Dewald et al. 1987).

The experiment was conducted at the U.S. Department of Agriculture, Agricultural Research Service's Southern Plains Range Research Station in Woodward, Oklahoma, USA $\left(36^{\circ} 27^{\prime} \mathrm{N}, 99^{\circ} 23^{\prime} \mathrm{W}, 556 \mathrm{~m}\right.$ elevation). In winter 1986, we randomly selected two families of full sibs segregating 1:1 for the pistillate phenotype from $F 1$ backcross families possessing at least 100 progeny. (The number of available progeny from each backcross was related to propagation techniques and was not a function of intrinsic parental fecundity.) Based on pilot studies in the preceding year, we ex- 


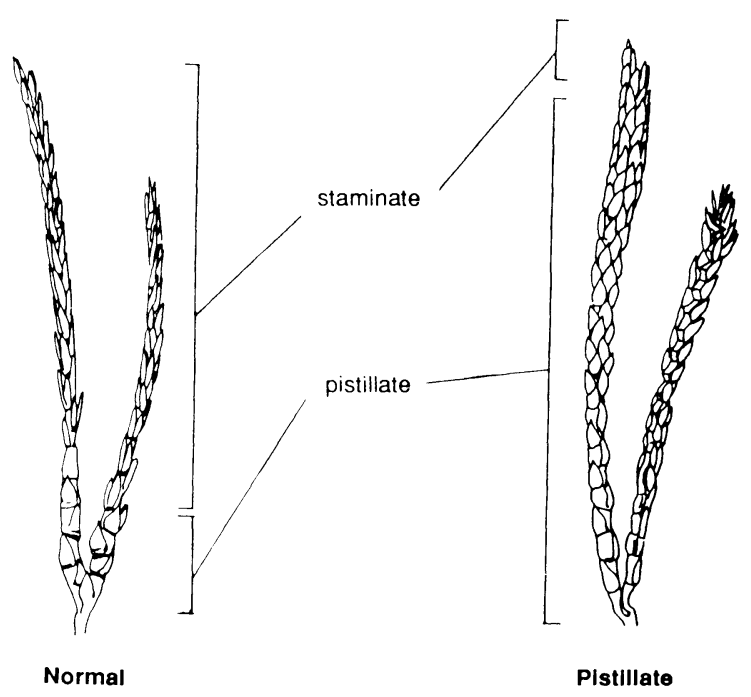

FIG. 1. Normal and pistillate inflorescences with staminate and pistillate portions identified $(0.375 \times$ actual size $)$.

pected any nonreproductive differences between normal and pistillate individuals to be subtle. Since the main objective was to compare otherwise similar individuals differing in reproductive effort, we opted for greater within-family replication at the expense of between-family replication.

Ten normal and 10 pistillate individuals were chosen at random to represent each family. Each individual was divided in March 1986 to make 24 clones. Clones were randomly assigned to 48 plots of 20 plants spaced $1.6 \mathrm{~m}$ apart such that 5 normal and 5 pistillate individuals from each family were represented in each plot. Each plot received a different random assortment of individuals, and no individual was allowed to appear in a plot more than once.

Transplants were watered at planting and later irrigated twice in June 1986, but only $78 \%$ of normal and $68 \%$ of pistillate plants survived the dry spring $\left(\chi^{2}=\right.$ $11.9, \mathrm{df}=1, P<.005)$. Except for one plot that was destroyed by mistake, plants were not manipulated until the experiment began in May 1988. Plots were located on Pratt sand 0.1-1 m deep overlying Permian redbed (bedrock). To control weeds, the fields were sprayed in April 1986-1988 with atrazine at a rate of $1.2 \mathrm{~kg} / \mathrm{ha}$ active ingredient and were cultivated 2-4 times each year. Nitrogen was applied at a rate of 67 $\mathrm{kg} / \mathrm{ha}$ (as ammonium nitrate) in April 1987 and 1988. Thus, the experiment was conducted under conditions of minimum competition for nitrogen and moderate to low competition for water.

\section{Experimental design and rationale}

The experiment was a $2 \times 3 \times 2$ factorial, split-plot design. Six treatments, a full combination of clipping vegetative tillers, and defoliation and removal of reproductive tillers (Fig. 2), were allocated to eight rep- licate whole plots. Normal and high-yielding pistillate plants were compared within plots. This design yielded relatively precise information about the effect of genotype, which was expected to be small, at the expense of information about response to manipulations, which was expected to be large (Sokal and Rohlf 1981).

In half of the plots, vegetative tillers were clipped to $5 \mathrm{~cm}$ every $2 \mathrm{wk}$ (referred to here as "biweekly clipping") from 1 May 1988 to 10 July 1988 (Fig. 2, Table 1). Three seed stalk treatments were applied factorially to the clipping treatments. Plants in $1 / 3$ of all plots were allowed to develop seed stalks (reproductive tillers) normally ("stalks intact"), while in another $1 / 3$ of the plots, leaves borne on the stalks were removed ("stalks defoliated"). In the remaining plots, all seed stalks were clipped at ground level as soon as they began to elongate and emerge from the vegetative canopy ("stalks removed") (Fig. 2, Table 1).

The first goal of the treatments was to expose, if possible, any differences in vegetative vigor between normal and pistillate plants. Clipping has been shown to reduce current photosynthate and carbohydrate and nutrient reserves (Richards and Caldwell 1985); in $T$. dactyloides, biweekly clipping will kill some plants within 2 mo (Jackson 1990). We predicted that if pistillate plants use a greater portion of their reserves during seed production or depend to a greater extent upon import of photosynthate from nearby vegetative tillers, then pistillate plants should be weaker than normal plants in some aspect of vigor, and clipping should exaggerate this difference.

The second goal was to compare the artificial manipulation of reproductive effort with genetically controlled differences in reproductive effort. Seed production was eliminated in the "stalks removed" treatment to compare reproducing with nonreproducing individ-

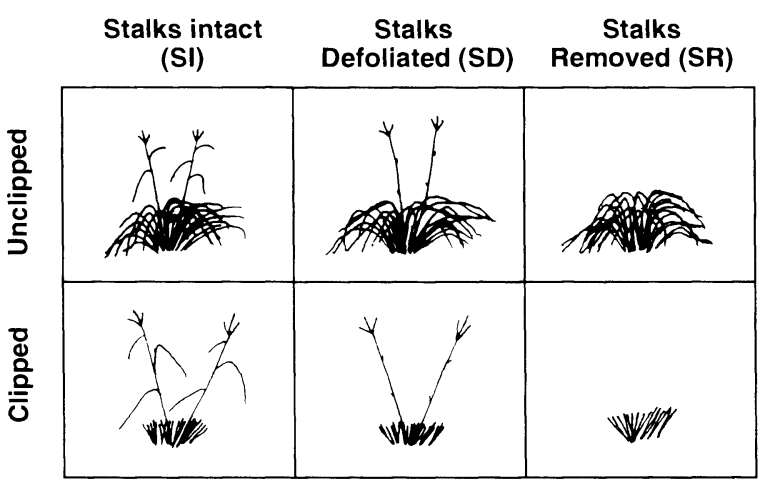

FIG. 2. Two-by-three factorial design of experimental manipulations. In the clipped treatment, vegetative tillers were clipped to $5 \mathrm{~cm}$ every $14 \mathrm{~d}$ for $10 \mathrm{wk}$ beginning 6 May 1988 . In the "stalks defoliated" treatment, leaf blades from each seed stalk were removed as soon as the stalk had begun to elongate. In the "stalks removed" treatment, stalks were severed at ground level as soon as they began to elongate. Stalk defoliation and removal were carried out as often as necessary to maintain completely treated plants (see Table 1). 
TABLE 1. Schedule of clipping and stalk treatments and measurements for plots harvested during peak flowering (F) and during seed ripening $(\mathrm{Sd})$, with number of plots affected shown in parentheses.

\begin{tabular}{|c|c|c|c|c|c|c|}
\hline $\begin{array}{c}\text { Dates } \\
(1988- \\
1989)\end{array}$ & $\begin{array}{l}\text { Clip veg. } \\
\text { tillers }\end{array}$ & $\begin{array}{l}\text { Defoliate } \\
\text { reprod. tillers }\end{array}$ & Basal area & $\begin{array}{l}\text { Count stalks or } \\
\text { collect infls. }\end{array}$ & $\begin{array}{l}\text { Aboveground } \\
\text { mass }\end{array}$ & $\begin{array}{c}\text { Belowground } \\
\text { mass }\end{array}$ \\
\hline 28 April & & $F, S d(31)$ & $F, S d(47)$ & & & \\
\hline 14 May & $\mathrm{F}, \mathrm{Sd}(24)$ & $\mathrm{F}, \mathrm{Sd}(31)$ & & & & \\
\hline 23 May & $\mathrm{F}, \mathrm{Sd}(24)$ & $\mathrm{F}, \mathrm{Sd}(31)$ & & & & \\
\hline 1 June & & $\mathrm{F}, \mathrm{Sd}(31)$ & $\mathrm{F}, \mathrm{Sd}(47)$ & & & \\
\hline 6 June & Sd (12) & $\operatorname{Sd}(16)$ & & count $F, S d(31)^{*}$ & & \\
\hline $\begin{array}{l}8-11 \text { June } \\
\text { 20 June }\end{array}$ & $\mathrm{Sd}(12)$ & $\mathrm{Sd}(16)$ & & & $\mathrm{F}(23)$ & $\mathrm{F}(23)$ \\
\hline 27-29 June & & & & count $\mathrm{Sd}(16) \dagger$ & & \\
\hline $\begin{array}{l}2-5 \text { July } \\
7-14 \text { July }\end{array}$ & Sd (12) & Sd (16) & $\mathrm{F}, \mathrm{Sd}(47)$ & collect Sd (16) & Sd (24) & Sd (24) \\
\hline 31 May 1989 & & & $\mathrm{~F}, \mathrm{Sd}(47)$ & count $F, S d(47)$ & $\mathrm{F}, \mathrm{Sd}(47)$ & Su $(24)$ \\
\hline
\end{tabular}

uals of both genotypes. If artificial and natural differences in reproductive effort are in fact comparable, then any costs revealed by manipulation should also be observed in the genetically induced contrast between normal and pistillate plants.

The third goal was to learn how the photosynthetic requirements of reproduction in gamagrass are met and whether normal and pistillate plants differ in their use of photosynthetic structures. For instance, it is possible that normal plants derive all their carbohydrates for seed production from the inflorescence and seed stalk leaves, while pistillate plants must supplement this with energy from current photosynthesis or reserves from neighboring vegetative tillers. We reasoned that if seed stalks are independent of vegetative tillers and tiller bases for resources, then seed production should only be affected by reducing leaf area on the seed stalk but not by clipping vegetative tillers. Clipping vegetative tillers and defoliating reproductive stalks should produce maximum stress, particularly on pistillate plants. A statistically significant interaction between defoliation treatments and genotype (normal vs. pistillate) would indicate that the two genotypes were relying on different sources for seed fill.

\section{Plant growth and reserves}

Measures of plant basal area, biomass production, and carbohydrate reserves were conducted at two phenological stages, peak flowering (2-9 June 1988) and peak seed ripening (7-14 July 1988) (Table 1 ). Based on data from previous experiments (Jackson 1990), we considered these phenological stages to be strategic for comparison of normal and pistillate plants. During peak flowering, carbohydrate storage in Tripsacum dactyloides is near minimum (Dewald and Sims 1981), so plants should be most vulnerable to defoliation. Comparisons at peak seed ripening maximize the cumulative difference between normal and pistillate demands for seed fill. We randomly assigned the eight replicate plots in each treatment to one of the two sampling dates.
Plant basal area, as estimated by circumference, was used as a nondestructive measure of plant size before, during and $1 \mathrm{yr}$ after experimental treatments (Table 1). Aboveground biomass production was calculated by summing biomass collected during destructive harvest and experimental manipulations (Table 2).

To estimate belowground shoot biomass, we dug up eight plants per plot and separated them into shoot systems consisting of one spent reproductive tiller and all attached secondary and tertiary tillers. We recorded the total number of shoot systems and then randomly selected three from each plant. From these we cleaned, separated, and counted vegetative and reproductive tiller bases. Tiller bases were frozen in a nondefrosting freezer for later fresh volume and dry mass measurement. Belowground biomass for the whole plant was estimated by multiplying the sample mean dry mass per shoot system in the subsample by the whole plant total.

Since carbohydrate reserves are correlated with the density of the storage organ (Wolf 1978, Lubbers and Lechowicz 1989) we used tiller base density as a metric of carbohydrate reserves. We determined the volume of fresh tiller bases by water displacement. Density was calculated as dry mass per unit stem volume (grams per millilitre), and analyzed by ANOVA. To determine whether the density of tiller bases was a reasonable measure of storage reserves, 158 tiller bases, representing the full range of densities, were dried and ground to pass a $0.25-\mathrm{mm}$ mesh screen for analysis of total nonstructural carbohydrate (TNC). Analysis was performed by the Colorado State University Chemical Analysis Laboratory, Boulder, Colorado, USA using a standard acid hydrolysis (Smith et al. 1964). Percent TNC was correlated with tiller base density $(r=0.72$, $P<.01)$.

\section{Components of seed yield}

Seed yield and yield components were measured on all plants in the "stalks intact" and "stalks defoliated" treatments scheduled for late destructive harvest (Ta- 
TABLE 2. Method of estimating cumulative, above- and belowground biomass production, and sample numbers. Clipping treatment affected sampling of vegetative biomass, and seed stalk treatment affected sampling of reproductive biomass, so sampling methods for each treatment are shown separately.

\begin{tabular}{|c|c|c|c|}
\hline Biomass component & Method & Plants & Plots \\
\hline \multicolumn{4}{|l|}{ Aboveground } \\
\hline \multicolumn{4}{|l|}{ Vegetative tillers } \\
\hline Unclipped & Final harvest & 174 & 12 \\
\hline Clipped biweekly & $\begin{array}{l}\text { Sum, five biweekly clippings and final harvest of vegetative } \\
\text { tillers }\end{array}$ & 186 & 12 \\
\hline \multicolumn{4}{|l|}{ Reproductive tillers } \\
\hline Stalks intact & Final harvest & 125 & 8 \\
\hline Stalks defoliated & Sum, subsample of stalk defoliation and final harvest & $\begin{array}{r}32 \\
114\end{array}$ & $\begin{array}{l}8 \\
8\end{array}$ \\
\hline Stalks removed & Sum, subsample of stalk removals & 32 & 8 \\
\hline \multicolumn{4}{|l|}{ Belowground } \\
\hline Vegetative tillers & Shoot system number $\times$ mean dry mass of a subsample & 190 & 24 \\
\hline Reproductive tillers & Same as above & 190 & 24 \\
\hline
\end{tabular}

ble 1). Typically, components of seed yield in cereal grasses are obtained by subsampling plants, inflorescences, and seeds. It was necessary to modify this approach substantially for $T$. dactyloides. Plant size varies, making it necessary to express stalk number on a per unit plant size basis. Furthermore, both terminal and lateral inflorescences are produced, which differ in size and spikelet composition and must be accounted for separately. Finally, inflorescence size varies greatly, making it necessary to express seed mass per unit inflorescences mass rather than per inflorescence. Therefore, the measurable components of seed yield for $T$. dactyloides are seed stalks per square centimetre basal area, inflorescences per stalk, mass per inflorescence, and seed mass and number per gram of inflorescence, in each case accounting for terminal and lateral inflorescences separately.

Plant basal area was determined 28 April and 2 July 1988 and again in May 1989 by measuring plant circumference, assuming each was a circle. In other studies using same-aged plants, the correlation (Pearson's $R$ ) between basal area and aboveground dry mass of previously unmanipulated plants was $0.91(y=0.116 x$ - 2.303; where $y=$ basal area in square centimetres, $x=$ grams dry mass, $N=360$ plants).

Terminal inflorescences ( $=$ seed stalks) were censused on 6 June, when $>95 \%$ of inflorescences had emerged, as determined by past years' data. Lateral inflorescences were censused on 27-29 June, due to the time lag between terminal and lateral inflorescence production (Jackson 1990). Between 27 and 29 June we collected and dried to constant mass all complete terminal and lateral inflorescences that were in the latter stages of seed ripening (defined as glumes beginning to turn brown) but had not yet begun to shatter. Wholeplant inflorescence mass was calculated from sample dry mass and censused number of inflorescences.

To obtain number and mass of seeds within inflorescences, all of the seed heads collected from each plant were separated into individual spikelets and mixed. We obtained a pseudorandom sample of $1.0 \mathrm{~g}$ of spikelets and extracted, counted, and determined mass of all the seeds within the sample. Total seed mass (number) for each plant was estimated by multiplying censused inflorescence number, mean inflorescence mass, and seed mass (number) per gram inflorescence. We handled terminal and lateral inflorescences separately until they were summed in the final step.

\section{Statistical analysis of seed yield and growth rate}

Components of seed yield are commonly analyzed by calculating a ratio, such as seeds per inflorescence, and then statistics are calculated for the means of the ratios. We wished to avoid this method where possible because of the problems associated with analysis of variance on ratios (Snedecor and Cochran 1980). Also, traditional means analysis provides mean seed yield per plant, but this number is dependent upon the size distribution of plants in the study. By looking explicitly at the reproductive behavior of plants in a range of sizes, as has been suggested by Weiner (1988) and Samson and Werk (1986), it is possible to avoid errors associated with ratios, explicitly examine the size-fecundity relationship, and compare seed yield results across studies.

Seed yield within the inflorescence (seed mass per inflorescence mass, number of seeds per gram inflorescence, and milligrams per seed) were analyzed by ANOVA because it is unlikely they were affected by total plant size. Other yield components (seed stalks per square centimetre of basal area, inflorescences per stalk, and mass and number of seeds per inflorescence) and total seed yield per square centimetre of basal area were analyzed by an extended ANCOVA in a threestep model reduction process (Allen and Cady 1982). First, for each treatment separately, we tested for linearity of the relationship between yield (the numerator of the yield component, e.g., seed stalks) and plant size 

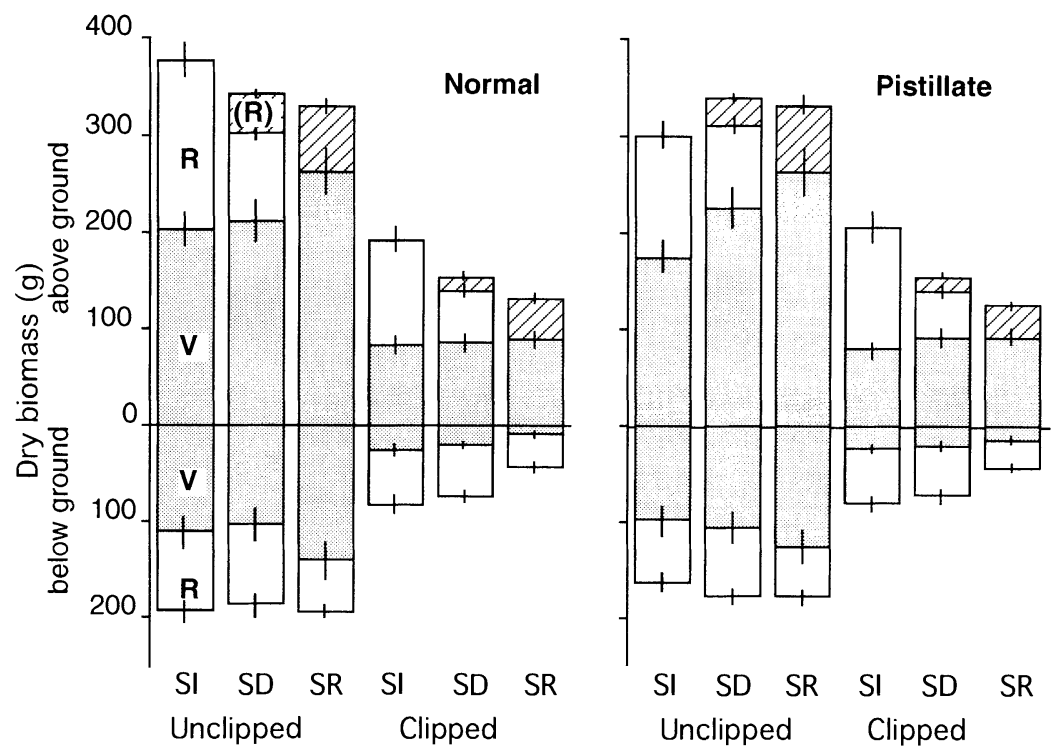

FIG. 3. Reproductive and vegetative biomass accumulated above- and belowground through the duration of the treatment period, 28 April to 5 July 1988 (least squares means $\pm 1 \mathrm{SE}$, back calculated from the log-transformed data). Method of obtaining biomass components and sample numbers are as given in Table 2, except that reproductive tiller biomass removed in the course of experimental manipulations ( $R$, light shading) is shown separately from that removed at destructive harvest ( $\mathrm{R}$, no shading). It was possible to distinguish belowground reproductive biomass in the "stalks removed" treatment because the remaining tiller bases of reproductive stalks differ morphologically from those of vegetative tillers.

(the denominator of the yield component, e.g., basal area) by fitting a quadratic model and testing for significance of the quadratic term. In all cases, the relationship between the two elements was best described by a reduced, linear model. Second, we ran a full ANCOVA model, using the yield component denominator as the covariate, which fit a separate mean and slope for each treatment. In all cases, the means effects were not significant, while interactions with the covariate (slopes) were highly significant. These results justified reduction of the models to a single intercept (Allen and Cady 1982). In all cases, this common intercept was close to zero. For instance, the full model, separate means regression of seed mass in grams $(y)$ vs. initial plant basal area in square centimetres $(x)$ had an intercept of $9.6 \pm 4.65 \mathrm{~cm}^{2}$ basal area (mean $\pm 1 \mathrm{SE}$ ). Although this intercept was significantly $>0(P=.04)$, a plant of this size would consist of no more than two tillers, very close to the smallest plant possible.

Finally, we simplified the model by replacing the intercept with zero, using NOINT in the General Linear Models Procedure of SAS (SAS 1985). This step both simplified the model and made it possible to interpret directly the beta coefficient estimate for each 1 df model effect as a component of yield, and it had no effect on the outcome of significance tests. We felt this step to be defensible in theory, because it is impossible for an intercept of a yield component to be $>0$ (a plant of zero size cannot have $>0$ seeds). It is possible for a plant to have a negative intercept if it must achieve a minimum size before flowering, but this was not observed. Nonzero intercepts mainly reflected our method of measurement, which became imprecise at small plant sizes. Contrasts were limited to the $1 \mathrm{df}$ contrasts provided by the main effects and interactions in the models.

We measured the change in basal area from April to June 1988 , April to July 1988 , and July 1988 to June 1989 , using the extended analysis of covariance methods described above. Basal area at a given date was found to be a linear function of basal area on the previous measurement date. Therefore, treatment effects on growth rate in basal area were estimated by regressing later vs. earlier basal area. A model was chosen that fit a single, nonzero intercept and separate slopes for each defoliation and genotype treatment (Allen and Cady 1982). Because the intercept in each case was not equal to zero, the slopes are not directly interpretable as growth rates, but within an ANCOVA the slopes of different treatments can be directly compared. A larger (or steeper) slope means a greater rate of growth.

\section{RESULTS \\ Plant growth and reserves}

Plant biomass, including seed stalks but not inflorescences, was measured by destructive harvest in June and July, but results of the two harvests were similar, so only data from the late harvest (July 1988) are presented (Fig. 3; Table 3). Genotype had no effect on total plant size, or any component of plant size, aboveor belowground, nor did normal and pistillate plants differ in their response to experimental manipulations.

Biweekly clipping of vegetative tillers repeatedly re- 
TABLE 3. ANCOVAs for the effect of experimental manipulations and genotype on the natural logarithm of above- and belowground biomass of vegetative and reproductive shoots excluding inflorescences, during peak flowering (July 1988). $\$$

\begin{tabular}{|c|c|c|c|c|c|c|}
\hline \multirow[b]{3}{*}{ Source } & \multirow[b]{3}{*}{$\mathrm{df}$} & \multicolumn{5}{|c|}{$F$ statistics } \\
\hline & & \multicolumn{2}{|c|}{ Vegetative } & \multicolumn{2}{|c|}{ Reproductive } & \multirow[b]{2}{*}{ Total\| } \\
\hline & & Above & Below & Abovef & Below & \\
\hline Clip (Cl) & 1 & $387.7 \ddagger$ & $693.5 \ddagger$ & $16.4 \dagger$ & $39.1 \ddagger$ & $520.0 \ddagger$ \\
\hline Stalk (S) & 2 & $7.6 \dagger$ & $5.0^{*}$ & $49.0 \neq$ & $26.5 \ddagger$ & $14.0 \ddagger$ \\
\hline $\mathrm{Cl} \times \mathrm{S}$ & 2 & 1.8 & $20.4 \ddagger$ & $1.9^{\circ}$ & 1.7 & $14.4 \ddagger$ \\
\hline Genotype (G) & 1 & 0.0 & 0.1 & 1.4 & 2.3 & 0.8 \\
\hline $\mathrm{Cl} \times \mathrm{G}$ & 1 & 0.2 & 1.5 & 2.3 & 0.1 & 0.8 \\
\hline$S \times G$ & 2 & 0.9 & 1.4 & 0.0 & 0.0 & 0.7 \\
\hline $\mathrm{Cl} \times \mathrm{S} \times \mathrm{G}$ & 2 & 0.1 & 1.8 & 2.7 & 0.9 & 0.6 \\
\hline Basal area & 1 & $527 \ddagger$ & $262 \ddagger$ & $287 \ddagger$ & $434 \ddagger$ & $927 \ddagger$ \\
\hline Error I df\# & & 18 & 18 & 11 & 18 & 18 \\
\hline Error II df & & 153 & 153 & 94 & 153 & 153 \\
\hline Model $R^{2}$ & & 0.90 & 0.88 & 0.85 & 0.84 & 0.93 \\
\hline
\end{tabular}

$* P<.05 ; \dagger P<.005 ; \ddagger P<.0005$.

$\S$ Initial basal area, measured in April 1988 prior to the onset of experimental manipulations, is used as a covariate so that treatment differences reflect growth since the beginning of the experiment.

$\|$ The sum of below- and aboveground biomass at harvest, and biomass removed by all defoliation treatments.

I Includes the dry mass of reproductive stalks at the end of the treatment period. $\mathrm{df}=1$ for all stalk main effects and interactions because only stalks intact and stalks defoliated treatments were included in this model.

\# Error term used to test clip, stalk, and clip $\times$ stalk effects.

duced photosynthetic area and therefore restricted total biomass production. Aboveground biomass of vegetative tillers, including all biomass removed during the clipping treatments, was $54-66 \%$ of unmanipulated plants. Likewise, clipping reduced the mean dry mass of seed stalks in plants with stalk leaves removed by $40-42 \%$. Biweekly clipping reduced vegetative tiller base biomass by $77-93 \%$ across treatments and reproductive tiller base biomass by $12-46 \%$.

Stalk removal increased the aboveground mass of vegetative tillers by $22-33 \%$ in unclipped plants and $8-15 \%$ in clipped plants. Clipping and stalk manipulation interacted significantly in their effects below ground. Stalk removal increased belowground biomass in unclipped plants by $20-22 \%$, while decreasing belowground biomass in plants that were also clipped by $35-65 \%(P<.0005$, Table 3$)$.

Total plant biomass produced through July diminished in order of increasing severity of defoliation (unclipped control $>$ unclipped, stalk leaves removed $>$ unclipped, stalks removed $\gg$ clipped control $>$ clipped, stalk leaves removed $>$ clipped, stalks removed). Unclipped plants were able to compensate partially for stalk defoliation and removal, but plants whose vegetative tillers were also clipped did not have this ability (Fig. 3, Table 3).

The effects of biweekly clipping in 1988 on plant biomass were still evident when remaining plants were harvested in June $1989(F=21.2, \mathrm{df}=1,18 ; P=$ .0002 ), but other treatments had no lasting effect (for seed stalk manipulations $F=0.14, \mathrm{df}=1,18 ; P=.87$; for genotype, $F=0.04$, df $=1,138 ; P=.83$ ).

Basal area expanded as a function of new tiller production and outward growth of existing tillers. Normal and pistillate plants expanded in basal area at the same rate throughout the experiment and the following year (Fig. 4; Table 4), and did not differ in their response to defoliation treatments as indicated by nonsignificant interaction terms. Biweekly clipping of vegetative til-

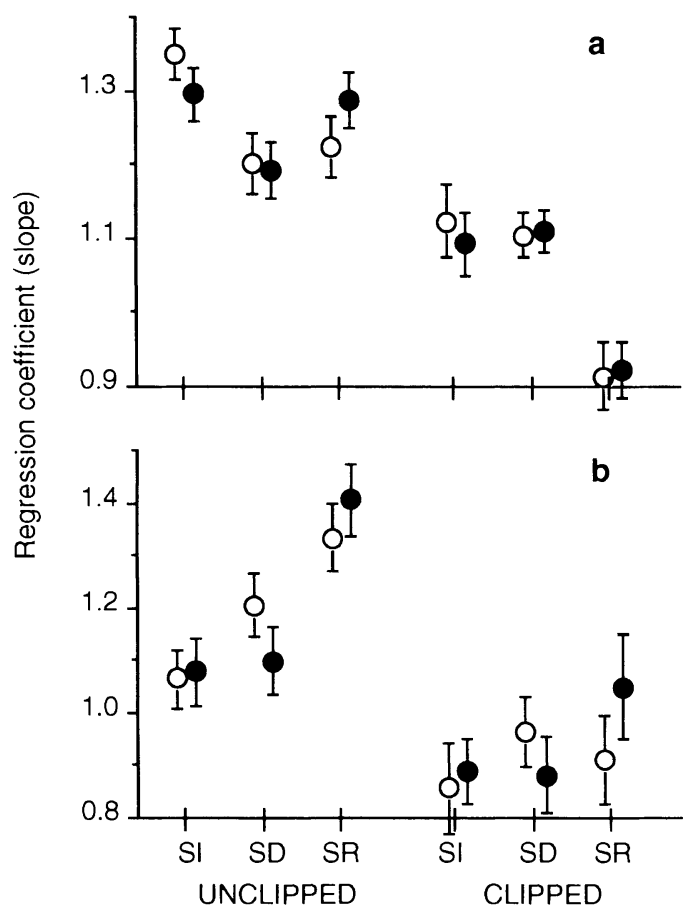

FIG. 4. Rate of change in basal area for normal $(O)$ and pistillate (๑) plants, during (a) 28 April 1988 to 5 July 1988 and (b) in the year following experimental manipulations from 5 July 1988 to 6 June 1989. Values are the mean ( $\pm 1 \mathrm{SE}$ ) slopes of final basal area vs. initial basal area, as estimated by extended ANCOVA (see Table 4). Experimental manipulations as in Fig. 2. 
TABLE 4. Effects of clipping and stalk defoliation on plant growth rate during treatment (28 April-5 July 1988) and the year after treatment (5 July 1988-6 June 1989) tested by extended ANCOVA.§

\begin{tabular}{lccc}
\hline \hline & & \multicolumn{2}{c}{$F$ statistics } \\
\cline { 3 - 4 } Source of variation & df & $\begin{array}{c}\text { During } \\
\text { treatment }\end{array}$ & $\begin{array}{c}1 \text { yr after } \\
\text { treatment }\end{array}$ \\
\hline Initial basal area (BA) & 1 & $4017 \ddagger$ & $731 \ddagger$ \\
$\mathrm{BA} \times \mathrm{Clip}(\mathrm{Cl})$ & 1 & $100 \ddagger$ & $53 \ddagger$ \\
$\mathrm{BA} \times \mathrm{Stalk}(\mathrm{S})$ & 2 & $12 \ddagger$ & $10 \ddagger$ \\
$\mathrm{BA} \times \mathrm{Cl} \times \mathrm{S}$ & 2 & $13 \ddagger$ & 2 \\
$\mathrm{BA} \times \mathrm{Genotype} \mathrm{(G)}$ & 1 & 0 & 0 \\
$\mathrm{BA} \times \mathrm{Cl} \times \mathrm{G}$ & 1 & 0 & 0 \\
$\mathrm{BA} \times \mathrm{S} \times \mathrm{G}$ & 2 & 1 & 2 \\
$\mathrm{BA} \times \mathrm{Cl} \times \mathrm{S} \times \mathrm{G}$ & 2 & 0 & 0 \\
Error df & & 343 & 157 \\
Model $R^{2}$ & & 0.92 & 0.78 \\
Intercept & & 102 & 75 \\
\hline$* P<.05 ;+P<.005 ; * P<$
\end{tabular}

$* P<.05 ; \dagger P<.005 ; \ddagger P<.0005$.

$\S$ The covariate is basal area (BA) in $\mathrm{cm}^{2}$ at the beginning of the growth period (28 April 1988 or 5 July 1988); and the dependent variable is basal area at the end of the growth period (5 July 1988 or 6 July 1989). Each model tests for differences in slopes (final basal area as a function of initial basal area) among treatments.

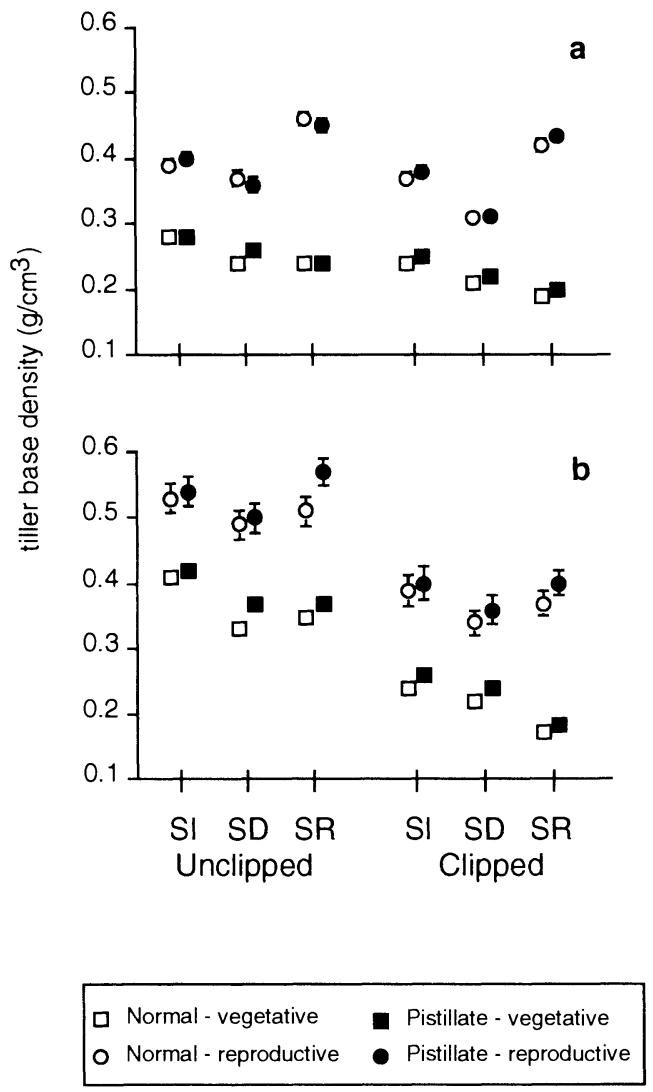

FIG. 5. Belowground storage of vegetative and reproductive tillers for normal and pistillate plants, as estimated by tiller base densities. (a) Densities at peak flowering (June). (b) Densities at peak seed ripening (July). Means are shown \pm 1 $\mathrm{SE}$, unless the standard errors are smaller than the symbols. lers greatly reduced basal area expansion and interacted significantly with stalk manipulation. Among unclipped plants, those with stalk leaves removed grew slowest, while among clipped plants, those with stalks removed grew slowest during the season in which they were clipped. In the 11 mo following the termination of experimental manipulations, the effects of stalk removal were now reversed: plants whose stalks had been removed in 1988 grew faster than the other treatments (Fig. 4; Table 4).

Normal and pistillate types differed significantly in carbohydrate storage, as estimated by tiller base density (dry mass per unit volume) but not in the predicted direction (Table 5; Fig. 5). Vegetative tiller bases of pistillate plants were significantly more dense than those of normal plants at both sampling dates, and reproductive tiller (seed stalk) bases of pistillate plants were denser than those of normal plants on the last sampling date. Tiller bases of reproductive stems did not have greater concentrations of total nonstructural carbohydrates (TNC) than vegetative stems because the relationship between density and percent TNC differed for the two stem types. Percent TNC varied from 2.12 to $14.73 \%$ among the subsample of stems analyzed.

Biweekly clipping and stalk defoliation and removal reduced tiller base densities (Fig. 5). Although tiller base densities of clipped plants in June were about the same $\left(0.19-0.25 \mathrm{~g} / \mathrm{cm}^{3}\right.$ for vegetative tillers) as those for clipped plants in July $\left(0.15-0.24 \mathrm{~g} / \mathrm{cm}^{3}\right)$, the plants looked much healthier in June, indicating that the relationship between plant carbohydrate status and health is partially a function of season.

\section{Components of seed yield}

Because the "stalks removed" treatments were not allowed to flower, components of yield could only be calculated for "stalks intact" and "stalks defoliated"

TABLE 5. ANOVAs of the effects of experimental manipulation and genotype on tiller base densities of reproductive and vegetative shoots during flowering and seed ripening. Tiller base density $(\mathrm{g} / \mathrm{mL})$ estimates carbohydrate storage.

\begin{tabular}{|c|c|c|c|c|c|}
\hline \multirow[b]{3}{*}{ Source } & \multirow[b]{3}{*}{$\mathrm{df}$} & \multicolumn{4}{|c|}{$F$ statistics } \\
\hline & & \multicolumn{2}{|c|}{$\begin{array}{l}\text { Flowering } \\
\text { (June) }\end{array}$} & \multicolumn{2}{|c|}{$\begin{array}{l}\text { Seed ripening } \\
\text { (July) }\end{array}$} \\
\hline & & $\begin{array}{l}\text { Vegeta- } \\
\text { tive }\end{array}$ & $\begin{array}{l}\text { Repro- } \\
\text { ductive }\end{array}$ & $\begin{array}{l}\text { Vegeta- } \\
\text { tive }\end{array}$ & $\begin{array}{l}\text { Repro- } \\
\text { ductive }\end{array}$ \\
\hline Clip (Cl) & 1 & $24.7 \ddagger$ & $22.3 \ddagger$ & $181.3 \ddagger$ & $148.4 \ddagger$ \\
\hline Stalk (S) & 2 & $13.6 \neq$ & $60.8 \ddagger$ & $8.5 \dagger$ & $4.6^{*}$ \\
\hline $\mathrm{Cl} \times \mathrm{S}$ & 2 & 0.1 & 1.1 & 2.1 & 0.1 \\
\hline Genotype (G) & 1 & $5.3^{*}$ & 0.1 & $14.4 \ddagger$ & $9.3 \dagger$ \\
\hline $\mathrm{Cl} \times \mathrm{G}$ & 1 & 0.1 & 0.4 & $0.1^{\circ}$ & 0.1 \\
\hline$S \times G$ & 2 & 0.6 & 0.0 & 0.5 & 1.1 \\
\hline $\mathrm{Cl} \times \mathrm{S} \times \mathrm{G}$ & 2 & 0.3 & 1.5 & 0.0 & 0.0 \\
\hline Error I df§ & & 17 & 17 & 18 & 18 \\
\hline Error II df & & 151 & 152 & 156 & 154 \\
\hline Model $R^{2}$ & & 0.56 & 0.67 & 0.89 & 0.75 \\
\hline
\end{tabular}

${ }^{*} P<.05 ; \dagger P<.005 ; \ddagger P<.0005$.

$\S$ Error term used to test clip, stalk, and clip $\times$ stalk effects. 
TABLE 6. ANCOVAs for the effects of experimental manipulation and genotype on components of seed yield. $\S$

\begin{tabular}{|c|c|c|c|c|c|c|c|}
\hline \multirow[b]{3}{*}{$\begin{array}{l}\text { Dependent variable: } \\
\text { Covariate: } \\
\text { Source }\end{array}$} & \multirow[b]{3}{*}{$\mathrm{df}$} & \multicolumn{6}{|c|}{$F$ statistics } \\
\hline & & \multicolumn{2}{|c|}{ Terminal inflorescences } & \multicolumn{2}{|c|}{ Lateral inflorescences } & \multicolumn{2}{|c|}{ Whole plants } \\
\hline & & $\begin{array}{l}\text { No. stalks } \\
\text { Initial BA, } \mathrm{cm}^{2} \|\end{array}$ & $\begin{array}{l}\mathrm{g} \text { infls. } \\
\text { No. infls. }\end{array}$ & $\begin{array}{l}\text { No. infls. } \\
\text { No. stalks }\end{array}$ & $\begin{array}{l}\text { g infls. } \\
\text { No. infls. }\end{array}$ & $\begin{array}{l}\text { g seeds } \\
\mathrm{cm}^{2} \mathrm{BA}\end{array}$ & $\begin{array}{c}\text { No. seeds } \\
\mathrm{cm}^{2} \mathrm{BA}\end{array}$ \\
\hline Covariate $(\mathrm{C})$ & 1 & $7393 \ddagger$ & $2532 \ddagger$ & $1293 \ddagger$ & $1526 \ddagger$ & $1153 \ddagger$ & $1155 \ddagger$ \\
\hline $\mathrm{C} \times \operatorname{Clip}(\mathrm{Cl})$ & 1 & 0 & $88 \ddagger$ & $8^{*}$ & 0 & 0 & 1 \\
\hline $\mathrm{C} \times$ Stalk $(\mathrm{S})$ & 1 & 1 & $55 \ddagger$ & $406 \ddagger$ & $67 \ddagger$ & $177 \ddagger$ & $129 \ddagger$ \\
\hline $\mathrm{C} \times \mathrm{Cl} \times \mathrm{S}$ & 1 & $13 \ddagger$ & 3 & $27 \ddagger$ & 2 & 17 & 6 \\
\hline $\mathrm{C} \times \operatorname{Genotype}(\mathrm{G})$ & 1 & 3 & $569 \ddagger$ & $41 \ddagger$ & $142 \ddagger$ & $379 \ddagger$ & $667 \ddagger$ \\
\hline $\mathrm{C} \times \mathrm{Cl} \times \mathrm{G}$ & 1 & $4^{*}$ & $32 \ddagger$ & 0 & $5^{*}$ & $0^{\top}$ & 1 \\
\hline $\mathrm{C} \times \mathrm{S} \times \mathrm{G}$ & 1 & 0 & $15 \ddagger$ & 0 & $11 \dagger$ & $91 \ddagger$ & $86 \neq$ \\
\hline $\mathrm{C} \times \mathrm{Cl} \times \mathrm{S} \times \mathrm{G}$ & 1 & 2 & 1 & 1 & 0 & $6^{*}$ & 3 \\
\hline Error df & & $431 \pi$ & 213 & 213 & 213 & 213 & 213 \\
\hline$R^{2}$ & & 0.95 & 0.95 & 0.88 & 0.97 & 0.89 & 0.91 \\
\hline
\end{tabular}

${ }^{*} P<.05 ; \dagger P<.005 ; \ddagger P<.0005$.

$\S$ The dependent variable is regressed against the covariate to estimate a slope, e.g., stalks $/ \mathrm{cm}^{2}$ basal area, for the population of plants in each treatment. The intercept in each model is set to zero (NOINT in SAS General Linear Models Procedure, SAS 1985), so the beta coefficient associated with each model effect directly estimates the yield component (Fig. 6). Intercepts, when fit separately for each treatment, are very close to zero (see Fig. 7).

$\| \mathrm{BA}$, plant basal area measured before experimental manipulations.

I The first ANCOVA includes plants destructively harvested before flowering $(n=439)$. Other ANCOVAs use only the remaining plants $(n=221)$.

treatments. The number of seed stalks (= terminal inflorescence number) increased linearly with plant basal area within the range $30-1200 \mathrm{~cm}^{2}$, and there appeared to be no size threshold below which plants would not flower. Plant basal area accounted for $94.7 \%$ of the variation in stalk number, while all treatments accounted for only $0.3 \%$ of the variation (Table 6; Fig. $6 a)$. It is unlikely that seed stalk number could have been affected by defoliation, because floral differentiation of meristems occurred before the treatments were applied.

Lateral inflorescences were more sensitive to stalk defoliation treatments than other components of yield (Table 6; Fig. 6b). Biweekly defoliation of vegetative tillers stimulated lateral production on plants with stalk leaves intact, but suppressed lateral production on plants with stalk leaves also removed. Pistillate plants produced fewer lateral inflorescences per stalk than normal plants in every treatment.

Pistillate terminal inflorescences were 1.0-1.6 g heavier than normals in every treatment (Table 6; Fig. $6 \mathrm{~b})$. Terminal inflorescence mass of normal plants was reduced $0.2 \mathrm{~g}$ /inflorescence by both clipping and stalk defoliation, and the two treatments had completely additive effects. Pistillate inflorescences were more sensitive (reduced $0.4-0.8 \mathrm{~g} /$ inflorescence by each defoliation treatment) to defoliations. Lateral inflorescence

FIG. 6. Components of seed yield for terminal and lateral inflorescences of normal (open bars) and pistillate (filled bars) plants. Experimental manipulations as in Fig. 2. Values represent the slope of the regression of the yield component numerator (dependent variable) vs. denominator (covariate), determined for each treatment by extended ANCOVA (see Table 6). Error bars are +1 SE of the slopes.

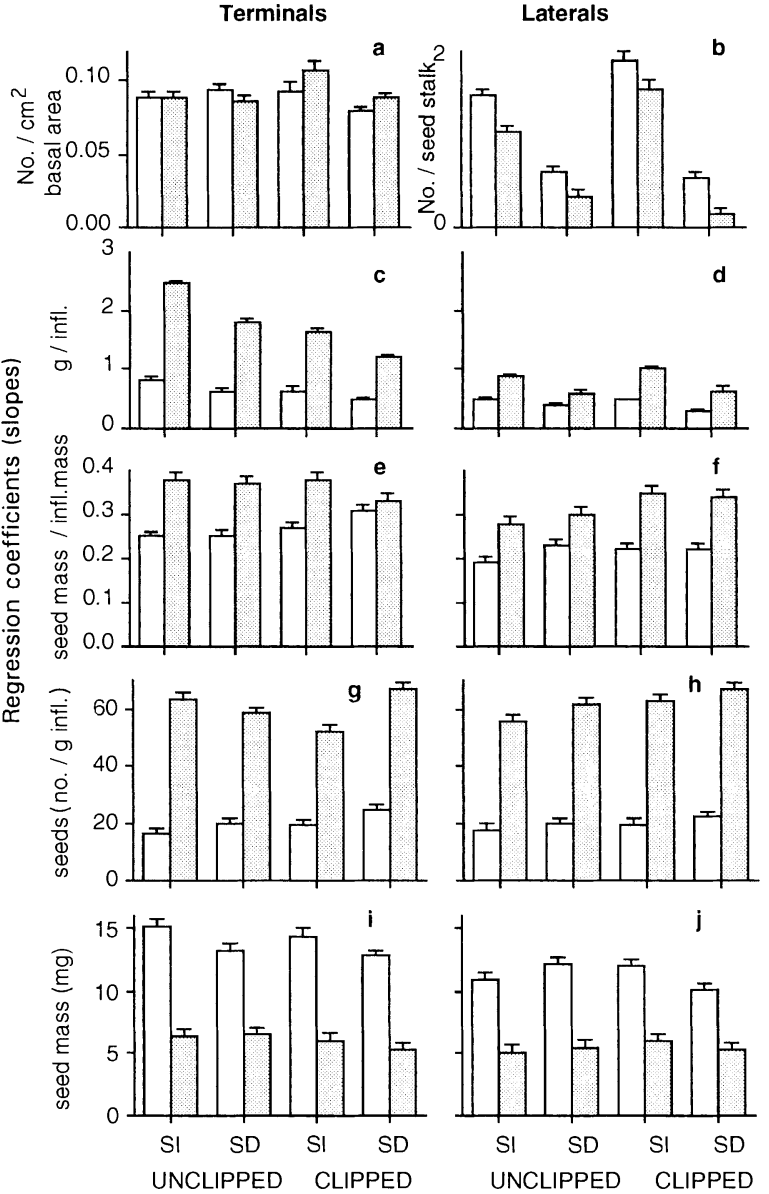


TABLE 7. ANOVAs for the effects of experimental manipulation and genotype on components of seed yield within terminal and lateral inflorescences (infl.). $\S$

\begin{tabular}{|c|c|c|c|c|c|c|c|}
\hline \multirow[b]{3}{*}{ Source } & \multirow[b]{3}{*}{$\mathrm{df}$} & \multicolumn{6}{|c|}{$F$ statistics } \\
\hline & & \multicolumn{3}{|c|}{ Terminals } & \multicolumn{3}{|c|}{ Laterals } \\
\hline & & $\begin{array}{l}\text { Seed mass/ } \\
\text { infl. mass } \\
(\mathrm{g} / \mathrm{g})\end{array}$ & $\begin{array}{l}\text { Seeds (no./ } \\
\text { g infl.) }\end{array}$ & $\begin{array}{l}\text { Seed mass } \\
(\mathrm{mg})\end{array}$ & $\begin{array}{c}\text { Seed mass/ } \\
\text { infl. mass } \\
(\mathrm{g} / \mathrm{g})\end{array}$ & $\begin{array}{l}\text { Seeds (no./ } \\
\text { g infl.) }\end{array}$ & $\begin{array}{l}\text { Seed mass } \\
(\mathrm{mg})\end{array}$ \\
\hline Clip (Cl) & 1 & 0.9 & 1.0 & 0.4 & $14.4 \dagger$ & $8.3 \dagger$ & 0.2 \\
\hline Stalk (S) & 1 & 0.1 & $11.8 \dagger$ & $5.5^{*}$ & 1.2 & $6.2^{*}$ & 0.6 \\
\hline $\mathrm{Cl} \times \mathrm{S}$ & 1 & 0.0 & $16.2 \ddagger$ & 0.7 & 4.5 & 0.0 & $10.5^{*}$ \\
\hline Error I & 11 & & & & & & \\
\hline Genotype $(G)$ & 1 & $93 \ddagger$ & $905 \ddagger$ & $317 \ddagger$ & $10.9 \ddagger$ & $838 \ddagger$ & $209 \ddagger$ \\
\hline $\mathrm{Cl} \times \mathrm{G}$ & 1 & $10.0 \dagger$ & 4.3* & 0.1 & $6.2^{*}$ & 2.2 & 1.2 \\
\hline $\mathrm{S} \times \mathrm{G}$ & 1 & $8.8 \dagger$ & 0.0 & 0.4 & 1.1 & 0.9 & 0.1 \\
\hline $\mathrm{Cl} \times \mathrm{S} \times \mathrm{G}$ & 1 & 3.3 & $11.9 \dagger$ & 3.2 & 0.0 & 0.1 & 1.7 \\
\hline Error II df & & 203 & 203 & 202 & 195 & 203 & 195 \\
\hline Model $R^{2}$ & & 0.40 & 0.83 & 0.65 & 0.44 & 0.81 & 0.55 \\
\hline
\end{tabular}

$* P<.05 ; \dagger P<.005 ; \ddagger P<.0005$.

$\S$ No covariate analysis was necessary; dependent variables are yield components, estimated for each plant by subsampling 1 -g spikelets from each plant and determining seed number and mass.

mass was reduced by stalk defoliation but not by clipping vegetative tillers (Table 6; Fig. 6d).

Although lateral inflorescences of pistillate plants consistently had greater mass than those of normal plants, the difference $(0.19-0.52 \mathrm{~g} /$ inflorescence $)$ was not as pronounced as in terminals (compare Fig. 6b, c).

Seeds comprised $33-38 \%$ of the mass of pistillate terminal inflorescences, compared to $25-31 \%$ for normals (Fig. 6e, f; $P<.0005$, Table 7). Terminal and lateral inflorescences maintained the same relative proportion of seed mass to inflorescence mass in all except the most severe treatment, but pistillate seed mass and seed mass per inflorescence mass responded to clipping treatments (Fig. 6f; Table 7).

Pistillate inflorescences produced 33-48 more seeds per unit inflorescence mass, each weighing about half (5-7 vs. 11-15 mg) the mass of a normal seed (Fig. $6 \mathrm{~g}$, $\mathrm{h}$; Table 7). The size of seeds within terminal inflorescences was significantly reduced by stalk defoliation but not clipping $(P<.05$; Table 7 , Fig. 6i, j). Among lateral inflorescences, clipping increased mass per seed when stalks remained intact, but defoliation of both stalks and vegetative tillers reduced seed mass relative to controls. This was consistent with the clipping effects on lateral inflorescence number and mass. We detected no interactions between genotype and defoliation treatments.

\section{Seed mass vs. plant size}

The overall response of seed mass and seed number per square centimetre of plant basal area to experimental manipulations was identical (last two columns of Table 6), so only seed mass will be discussed in detail here. Pistillate plants yielded more than normal plants of equivalent size in all treatments. Biweekly clipping had no net effect on seed yield (Fig. 7; Table
6) due to its opposite effect on terminal and lateral inflorescences. Stalk defoliation and genotype interacted strongly: pistillate plant yields were reduced far more than normal plant yields.

\section{Reproduction in the year after defoliation}

In the flowering season $1 \mathrm{yr}$ after we imposed defoliation treatments, the number of seed stalks remained constant across treatments at 0.068-0.079 stalks $/ \mathrm{cm}^{2}$ (grand mean $=0.071$ compared to 0.079 stalks $/ \mathrm{cm}^{2}$ for the same group of plants in 1988). Pistillate plants had slightly more stalks per square centimetre basal area $(F=3.65, \mathrm{df}=1,137 ; P=.0583)$; no other treatment came close to significance. No other component of yield was measured in 1989.

\section{Discussion}

Due to the economic importance of cereal and forage grasses, their morphological development, carbohydrate movement, and photosynthetic contribution of various organs to seed yield are perhaps better known than in any other plant family. This knowledge is essential in interpreting the response of $T$. dactyloides to defoliation and understanding the effects of the pistillate mutation.

A perennial grass in flower consists of two distinct classes of shoots, vegetative and reproductive. Depending on developmental stage and plant condition, reproductive tillers are completely dependent upon, independent from, or contributing to vegetative tillers, but at all times each tiller competes with other tillers for light, nutrients, and water. Each tiller (= "shoot") initially is dependent upon the tiller from which it arose (heterotrophic), and gradually grows enough leaves and roots to support itself (becomes autotrophic). Once autotrophic, a tiller can produce new, dependent tillers 

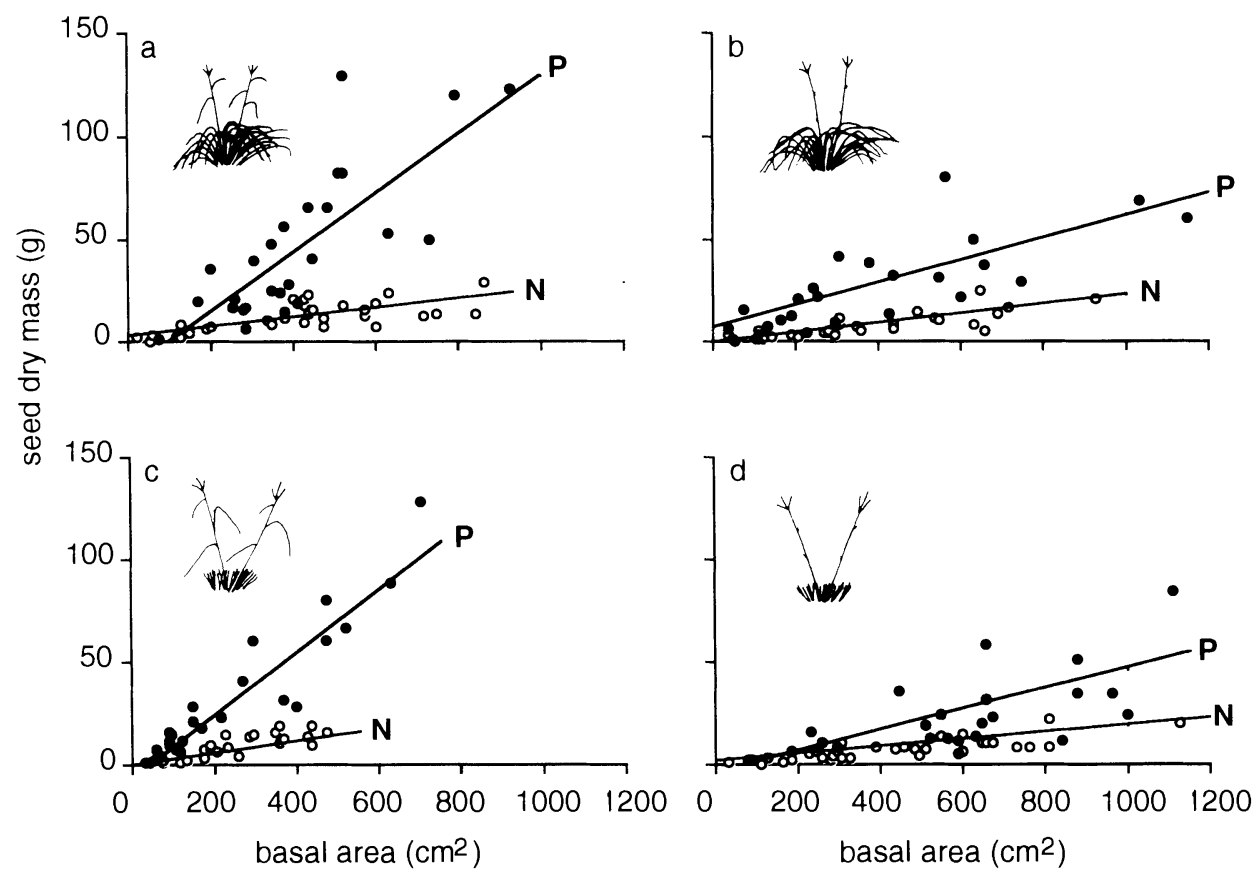

FIG. 7. Dry mass of seed per plant, as a function of plant size in basal area at the beginning of the growing season, for normal $(O)$ and pistillate $(\bullet)$ plants. Lines are best fit regressions (full model with separate slopes and intercepts; compare to Table 1), to show proximity of intercepts to the origin. Experimental manipulations as in Fig. 2.

using current and locally stored photosynthate (Williams 1964, Marshall and Sagar 1965, 1968, Jewiss 1972).

During flowering, the largest, oldest vegetative tillers undergo floral differentiation and once again become heterotrophic. In $T$. dactyloides this begins in early May before a full plant canopy has been established. The distal 4-6 internodes of each reproductive tiller elongate, in $10 \mathrm{~d}$, from $<4 \mathrm{~cm}$ to $>1 \mathrm{~m}$ and the terminal inflorescence grows from $<1 \mathrm{~cm}$ to $\approx 16 \mathrm{~cm}$ long ( $\mathrm{L}$. L. Jackson, unpublished data). This coincides with a sharp drop in total nonstructural carbohydrates in storage tissues throughout the plant (Dewald and Sims 1981). About $15 \mathrm{~d}$ later, now fully extended and autotrophic, the reproductive tiller initiates new tillers in the axils of stalk leaves. These tillers consist of two internodes only and are also reproductive (lateral inflorescences).

We first clipped vegetative tillers when most reproductive tillers were elongating and still heterotrophic. Clipping vegetative tillers reduced the size of reproductive tillers (Fig. 3; Table 3) and the size and seed yield of terminal inflorescences (Fig. 6c; Table 6). By our second clipping 2 wk later, most reproductive tillers had reached full size and had begun to initiate lateral tillers. Clipping vegetative tillers did not inhibit lateral inflorescence initiation (Fig. 6b) or final inflorescence size (Fig. 6 d; Table $6, F=0$ ) because by this time seed stalks were independent of vegetative tillers. In fact, clipping vegetative tillers stimulated lateral production (Table 6) and seed fill (Table 7). Lateral, more so than terminal, inflorescences are shaded by the vegetative canopy and may compete with it for light. Our data suggest that during flowering, each plant is a population of autotrophic tillers, all competing for light, water, and nutrients and against one another. In closely spaced plantations of $T$. dactyloides, lateral inflorescence production depends on light availability. On the open, outside edge of a plantation, a stalk may produce as many as 10 lateral inflorescences, while stalks facing the shady interior produce $0-1$ laterals (L. L. Jackson, unpublished data). The extreme sensitivity of lateral inflorescence seed yield to stalk defoliation supports this general picture of reproductive tiller autonomy.

An autonomous tiller can merely support itself (maintain leaves, grow new leaves or seeds, grow and maintain associated roots), or it can support itself and also grow new tillers, store carbohydrates, or export carbohydrates to other tillers. Gifford and Marshall (1973) and Ong and Marshall (1979) have shown using labeled carbon tracers that grass tillers will export carbohydrates to nearby, shaded or defoliated tillers. Although these studies were done on vegetative tillers, there is reason to believe the results extend to reproductive tillers in $T$. dactyloides. Our data showed that severely clipped plants with seed stalks intact had more vegetative biomass in July, higher carbohydrate storage in vegetative tiller bases in June and July, and faster rates of growth in basal area during the treatment period than did clipped plants with stalks removed or defoliated (Figs. $3-5)$. The significant interaction $(F=$ 
20.4) between clipping and stalk defoliation in the biomass of vegetative tiller bases further supports this idea. Rather than being a cost, reproductive tillers appear to support stressed plants. Ong et al. (1978) found that inflorescences of Poa annua exported ${ }^{14} \mathrm{C}$-labeled assimilate to other parts of the plant during the later stages of seed development.

The cost of reproduction in gamagrass occurs in three ways. First, actively growing meristems are sacrificed to a reproductive fate. This has been documented in other clonal plants (Watson 1984, Tortensson and Telenius 1986, Carlsson and Callaghan 1990). Second, stored reserves and current photosynthate and nutrients must be mustered to sponsor the initial growth of a seed stalk (Dewald and Sims 1981, Parsons and Robson 1981, Colvill and Marshall 1984). Finally, vegetative tillers must compete with reproductive tillers in the plant canopy. Plants whose stalks had been removed in 1988 grew faster in basal area during the following year (Fig. 4), possibly because vegetative tillers were released from competition with seed stalks, enabling them to produce more new tillers. None of these costs reflect the number or size of seeds produced on each stalk. Thus, the immediate carbon and nutrient requirements of producing seeds and pollen are partially decoupled from plant vegetative vigor and future reproduction.

Given the proposed model of reproductive cost described above, the pistillate mutation could create a trade-off in three ways. First, developing pistillate reproductive tillers could require a longer period of heterotrophy if building the seed stalk is more expensive. This could result in slower growth rates or lower carbohydrate reserves early in the flowering season. When we sampled plants in early June, after the spurt of stalk growth, we found equal or greater density of the tiller bases of pistillate plants (Table 5; Fig. 5a). Pistillate plants grew equally fast in basal area between April and June $(F=0.34, \mathrm{df}=1,691 ; P=.56$; ANCOVA model identical to Table 4), and were identical for all components of biomass in June (e.g., for total biomass, $F=0.1, \mathrm{df}=1,148 ; P>.1 ;$ ANCOVA model identical to Table 3).

Second, pistillate seed stalks could be less capable of supporting stressed vegetative tillers than normal plants, resulting in genotype $\times$ defoliation interactions in plant size, growth, or storage. There was a significant effect of genotype on tiller base densities at the end of the flowering period (Table 5; Fig. 5b), but the result was opposite that predicted: pistillate plants had denser tiller bases, implying greater stored reserves. Finally, greater stress in pistillate plants could show up in smaller plant size or fewer seed stalks in the year after manipulation, but this did not occur.

We found no evidence to suggest a trade-off in vegetative vigor for greater seed production during the growing season (April-October). We did observe higher mortality among pistillate clones after they were transplanted in March 1986. This could be related to the tendency for pistillate phenotypes to emerge from winter dormancy slightly earlier than normal (C. Dewald, personal observations). Transplant success is highest when plants are completely dormant (Dewald and Louthan 1979).

\section{Seed production within the stalk}

How, then, do pistillate plants achieve greater seed production? It is possible that the cost of extra seed production in pistillate plants is equivalent to the pollen production they forego. Based on dry mass measurements of 30 normal inflorescences collected before pollen shed and 30 collected after pollen shed, pollen biomass could be as much as $50 \%$ of the seed mass of a normal inflorescence. (Pollen production of pistillate plants in our study was on the order of $1 \%$ that of normal plants.) This would reduce but not eliminate the difference in total reproductive biomass in the two genotypes. It is also likely that pollen differs qualitatively from seeds in the energy or nutrient content per unit biomass or that its production earlier in the season than seeds poses costs greater than would be expected on the basis of biomass alone.

If, as we have posited, there is a net difference in the energy and nutrients associated with reproduction in normal and pistillate plants and costs of reproduction are borne locally, within the stalk, then we must examine the capacity of seed stalks and inflorescences to support seed production. Normal plants experienced little change in production when stalks were defoliated (a reduction in seed production of $0.019 \mathrm{~g} / \mathrm{cm}^{2}$ basal area), while pistillate plant seed production plummeted to near the level of normal seed production (a reduction of 0.101 to $0.041 \mathrm{~g} / \mathrm{cm}^{2}$ vs. $0.035 \mathrm{~g} / \mathrm{cm}^{2}$ for unmanipulated normal plants) (Fig. 7; Table 6). From these results one might conclude that normal plants are "overbuilt" or buffered, so that some seed production occurs even under conditions of severe defoliation, while pistillate plants are operating at very close to the limit of the stalk's ability to provide photosynthate. A conservative, "buffered" reproductive strategy, in which similar seed production is achieved under a variety of conditions from optimum to stressful, conceivably could have adaptive value in long-lived perennials. However, buffered strategies have neither been documented nor their implications thoroughly explored for perennial plants.

Alternatively, pistillate plants could have greater potential assimilation abilities, through, for example, greater sink strength, more stalk leaf area, or larger inflorescence size. This possibility is suggested by the result that even in the most severe defoliation treatments, pistillate plants had higher yields than normal plants. However, pistillate stalks filled more seeds with less leaf area. In a separate study, we found that normal and pistillate seed stalks did not differ in total dry mass excluding inflorescences $(P=.436)$ but that pistillate 
stalks were $11.5 \mathrm{~cm}$ shorter $(P<.0001)$ and possessed $20 \mathrm{~cm}^{2}$ less leaf area $\left(175\right.$ vs. $155 \mathrm{~cm}^{2} ; P=.057 ; N=$ $66)$. Pistillate inflorescences are larger than normal inflorescences, and it is feasible that their greater size accounts for some of the greater potential seed yield. No data are available for assimilation rates of inflorescences in Tripsacum, but Ong et al. (1978) measured ${ }^{14} \mathrm{CO}_{2}$ fixation in Lolium perenne and Poa annua inflorescences and flag (seed stalk) leaves. In a summary of their data and review of the extensive literature on flag leaf and inflorescence photosynthesis, they concluded that "the grass inflorescence, an assemblage of green leaf-like floral structures positioned in an ideal light environment, is a very active photosynthetic structure. ... (T)he inflorescence plays an important role in supporting seed development in both cereals and grasses."

Our data are not sufficient to determine exactly "how" greater seed production is achieved in the pistillate mutation of $T$. dactyloides, nor can we exclude the possibility that some trade-off exists. The search for such trade-offs, however, is misplaced: our energy would be better spent examining the genetic variation that is available within the species to change reproductive behavior, the developmental mechanisms by which this can take place, and their consequences for other aspects of fitness.

For example, the pistillate mutation in gamagrass increases seed production in part by reversing the gender of male florets. Since spikelets in normal gamagrass are sexually dimorphic, with pairs of staminate florets housed in small, open spikelets, (Fig. 1), the development of pistillate seeds is restricted by a small spikelet cavity. As a result, seeds from pistillate plants are $1 / 4$ to $1 / 2$ the mass of normal seeds, and germination and establishment are correspondingly poor (Jackson et al. 1992).

There are consequences at the level of the inflorescence and seed stalk as well. Seeds of pistillate plants are more susceptible to predation because they develop inside thin glumes adapted for pollen dispersal. The tendency in normal plants for the staminate section to break off after pollen shed is preserved to varying degrees in pistillate inflorescences, so many seeds are lost before reaching maturity. Finally, the pistillate seed stalk is no stronger than that of normal plants and can snap under its own seed mass before the seeds mature (L. L. Jackson, personal observations). The defects in pistillate plants caused by "architectural remnants" (Watson and Casper 1984), combined with low pollen production, more than offset the fitness benefits of greater seed production. Examination of the particular developmental consequences of the pistillate mutation has led to good predictions about its life history evolution, while detailed examination of resource allocation has not. The study of more subtle, quantitative variation in reproductive behavior of gamagrass and other species may be equally instructive.

\section{Physical vs. genetic manipulation of reproductive effort}

The manipulations of reproductive effort we imposed revealed a cost of reproduction (faster growth in basal area of plants with stalks removed, Fig. 4), while the comparison of normal and pistillate plants did not. Several recent studies of life history trade-offs in plants have focused on small, nonclonal herbs with a nonphotosynthetic inflorescence, few leaves, and a simple storage organ (Horvitz and Schemske 1988, Lubbers and Lechowicz 1989, Snow and Whigham 1989, Ackerman and Montalvo 1990, Primack and Hall 1990). It is likely that in these systems, flowering and vegetative growth are more tightly coupled than they are in perennial grasses, resulting in clearer trade-offs between current and future reproduction (but see Horvitz and Schemske 1988).

There are two difficulties in interpreting the results of an experimental manipulation of reproductive effort in evolutionary terms. First, experimental manipulation does not simply affect the resource costs of seed production. Removing an active floral meristem is likely to change growth regulation throughout the plant. This would be true whether reproduction were manipulated by removing the developing flower or fruit (e.g., Snow and Whigham 1989; this study), applying growth retardant (e.g., Hampton and Hebblethwaite 1985), or changing day length (e.g., Reekie and Bazzaz 1987a, $b, c)$. In this and other experiments we noted earlier tiller proliferation and earlier senescence among plants whose stalks had been removed (L. L. Jackson, unpublished data). These plants seemed to skip to a later part of their life cycle.

Second, manipulated contrasts may not simulate the kind of genetic variation available in the species to boost or retard seed production. In our study it was not feasible to increase seed production per inflorescence experimentally, so we could not mimic the pistillate mutation. With only information about the effects of removing seed stalks on normal plants, we might be justified in making inferences about genetic variation for the proportion of tillers that become reproductive, but not about inflorescence number or mass. Because of the historical focus on resource costs of reproduction, as opposed to morphological constraints, it has been assumed that the demographic consequences of changing reproductive effort are independent of the way that change is achieved. Our data suggest that this assumption is invalid.

More research needs to be done on genetic variation in reproductive effort (Reznick 1985) and the developmental means by which it is achieved. Lande (1982) emphasized the importance of negative genetic correlations in characters directly related to fitness, such as components of yield. Law et al.'s (1977) study of the correlations among age-specific fecundity, plant size, and risk of mortality of Poa annua (a short-lived pe- 
rennial grass) from different habitats and among maternal half-sib families within habitats is still the only such study on plants.

Tripsacum dactyloides is not unusual in the Andropogoneae for the changes in floral suppression and gender expression that increase seed production. Comparable mutations leading to increased seed number are found in Sorghum, Zea, Andropogon, and Bothriachloa (Karper and Stephens 1936, Harlan 1981, Boe et al. 1983, Gould and Shaw 1983, Finley and Ross 1984). However, unlike the other wild species in this taxon, gamagrass is in the beginning stages $(<20 \mathrm{yr})$ of domestication. For this reason the species is well collected and studied throughout its range; the pistillate mutation was discovered, characterized, and introduced into a variety of genetic backgrounds; and tillering and carbohydrate dynamics are fairly well understood, at least in a general way. Subsequent artificial selection has continued to uncover genetic variation for both vegetative and reproductive characteristics (C. L. Dewald, unpublished data). It is hard to imagine how the outcome of selection on a novel gene could be predicted with anything less than this level of understanding. The resource trade-off model may be able to describe patterns of resource distribution for a species in terms of "reproductive effort" or "allocation," yet remain unable to predict life history evolution.

\section{ACKNOWLEDGMENTS}

This work was part of a doctoral dissertation submitted to Cornell University. Research was supported by an NSF Graduate Fellowship to L. L. Jackson and an NSF grant to Deborah Rabinowitz. Additional support was provided by the Andrew Mellon Foundation. The authors are grateful to Deborah Rabinowitz (1947-1987) for many insightful comments; to P. Marks, D. Paolillo, C. Jensen, M. Geber, P. Kulakow, and two anonymous reviewers for helpful comments on the manuscript; to P. Dixon and D. Umbach for statistical support; and to M. Fields, S. Wersinger, and T. Fay for assistance in the field. The cooperation of the Southern Plains Range Research Station was indispensable in all aspects of this work.

\section{Literature Cited}

Abrahamson, W. G., and H. Caswell. 1982. On the comparative allocation of biomass, energy and nutrients in plants. Ecology 63:982-991.

Ackerman, J. D., and A. M. Montalvo. 1990. Short- and long-term limitations to fruit production in a tropical orchid. Ecology 71:263-272.

Allen, D. M., and F. B. Cady. 1982. Analyzing experimental data by regression. Lifetime Learning, Belmont, California, USA.

Boe, A., J. G. Ross, and R. Wynia. 1983. Pedicellate spikelet fertility in big bluestem from eastern South Dakota. Journal of Range Management 36:131-132.

Carlsson, B. A., and T. V. Callaghan. 1990. Effects of flowering on the shoot dynamics of Carex bigelowii along an altitudinal gradient in Swedish Lapland. Journal of Ecology 78:152-165.

Charnov, E. L. 1982. The theory of sex allocation. Princeton University Press, Princeton, New Jersey, USA.

Cole, L. C. 1954. The population consequences of life history phenomena. Quarterly Review of Biology 29:103-137.
Colvill, K. E., and C. Marshall. 1984. Tiller dynamics and assimilate partitioning in Lolium perenne with particular reference to flowering. Annals of Applied Biology 104:543557.

Dewald, C. L., B. L. Burson, J. M. J. DeWet, and J. R. Harlan. 1987. Morphology, inheritance and evolutionary significance of sex reversal in Tripsacum dactyloides (Poaceae). American Journal of Botany 74:1055-1059.

Dewald, C. L., and R. S. Dayton. 1982. A prolific sex form variant of eastern gamagrass. Phytologia 57:156.

Dewald, C. L., and V. H. Louthan. 1979. Sequential development of shoot system components in Eastern gamagrass. Journal of Range Management 32:147-151.

Dewald, C. L., and P. L. Sims. 1981. Seasonal vegetative establishment and shoot reserves of eastern gamagrass. Journal of Range Management 34:300-304.

Finley, W. F., and W. M. Ross. 1984. Comparison of twinand single-seeded $\mathrm{S} 1$ progenies from a sorghum population. Maydica 29:55-67.

Fox, J. F., and G. C. Stevens. 1991. Costs of reproduction in a willow: experimental responses vs. natural variation. Ecology 72:1013-1023

Gadgil, M., and W. H. Bossert. 1970. Life historical consequences of natural selection. American Naturalist 104: 124.

Gifford, R. M., and C. Marshall. 1973. Photosynthesis and assimilate distribution in Lolium multiflorum Lam. following differential tiller defoliation. Australian Journal of Biological Science 26:517-526.

Gould, F. W., and R. B. Shaw. 1983. Grass systematics. Second edition. Texas A\&M Press, College Station, Texas, USA.

Gross, K. L., and J. D. Soule. 1981. Differences in biomass allocation to reproductive and vegetative structures of male and female plants of a dioecious perennial herb, Silene alba (Miller) Kraus. American Journal of Botany 68:801-807.

Hampton, J. G., and P. D. Hebblethwaite. 1985. The effect of growth retardant application on floret site utilization in ears of perennial ryegrass cv. 24. Annals of Applied Biology 107:127-136.

Harlan, J. R. 1981. Human interference with grass systematics. Pages 37-50 in J. R. Estes, R. J. Tyrl, and J. N. Brunken, editors. Grasses and grasslands. University of Oklahoma Press, Norman, Oklahoma, USA.

Harper, J. L. 1977. The population biology of plants. Academic Press, New York, New York, USA.

Harper, J. L., and J. Ogden. 1970. The reproductive strategy of higher plants. I. The concept of strategy with special reference to Senecio vulgaris. Journal of Ecology 58:681698.

Hickman, J. D., and L. Pitelka. 1975. Dry weight indicates energy allocation in ecological strategy analysis of plants. Oecologia 21:117-121

Hole, C. C., and P. A. Scott. 1983. Effect of number and configuration of fruits, photon flux density and age on the growth and dry matter distribution of fruits of Pisum sativum L. Plant, Cell and Environment 6:31-38.

Horvitz, C. C., and D. W. Schemske. 1988. A test of the pollinator limitation hypothesis for a neotropical herb. Ecology 63:1363-1373.

Jackson, L. L. 1990. Life history consequences of greater seed production in a perennial grass, Tripsacum dactyloides: a comparison of high and low seed-yielding genotypes. Dissertation. Cornell University, Ithaca, New York, USA.

Jackson, L. L., C. L. Dewald, and C. C. Bohlen. 1992. A macromutation in Tripsacum dactyloides (Poaceae): consequences for seed size, germination, and seedling establishment. American Journal of Botany 79:1031-1038.

Jewiss, O. R. 1972. Tillering in grasses-its significance and control. Journal of the British Grassland Society 27:65-82. 
Karper, R. E., and J. C. Stephens. 1936. Floral abnormalities in sorghum. Journal of Heredity 27:183-194.

Lande, R. 1982. A quantitative genetic theory of life history evolution. Ecology 63:607-615.

Law, R. 1979. The cost of reproduction in annual meadow grass. American Naturalist 113:3-16.

Law, R., A. D. Bradshaw, and P. D. Putwain. 1977. Life history variation in Poa annua. Evolution 31:233-246.

Lovett Doust, J., and L. Lovett Doust. 1987. Leaf demography and clonal growth in female and male Rumex acetosella. Ecology 68:2056-2058.

Lubbers, A. E., and M. J. Lechowicz. 1989. Effects of leaf removal on reproduction vs. belowground storage in Trillium grandiflorum. Ecology 70:85-96.

Marshall, C., and G. R. Sagar. 1965. The influence of defoliation on the distribution of assimilates in Lolium multiflorum Lam. Annals of Botany 29:365-370.

Marshall, C., and G. R. Sagar. 1968. The distribution of assimilates in Lolium multiflorum Lam. following differential defoliation. Annals of Botany 32:715-719.

Ong, C. K., K. E. Colvill, and C. Marshall. 1978. Assimilation of ${ }_{14} \mathrm{CO}^{2}$ by the inflorescence of Poa annua L., and Lolium perenne L. Annals of Botany 42:855-862.

Ong, C. K., and C. Marshall. 1979. The growth and survival of severely shaded tillers in Lolium perenne L. Annals of Botany 43: 147-155.

Onwekwelu, S. S., and J. L. Harper. 1979. Sex ratio and niche differentiation in spinach (Spinacea oleracea L.). Nature 282:609-611.

Parsons, A. J., and M. T. Robson. 1981. Seasonal changes in the physiology of $\mathrm{S} 24$ perennial ryegrass (Lolium perenne L.). 3. Partition of assimilates between root and shoot during the transition from vegetative to reproductive growth. Annals of Botany 48:733-744.

Policansky, D. 1981. Sex choice and the size advantage model in jack-in-the-pulpit (Arisaema triphyllum). Proceedings of the National Academy of Sciences (USA) 78: 1306-1308.

Primack, R. B., and P. Hall. 1990. Costs of reproduction in the pink lady's slipper crchid: a four-year experimental study. American Naturalist 136:638-656.

Reekie, E. G., and F. A. Bazzaz. 1987a. Reproductive effort in plants. 1. Carbon allocation to reproduction. American Naturalist 129:876-896.

Reekie, E. G., and F. A. Bazzaz. 1987b. Reproductive effort in plants. 2. Does carbon reflect the allocation of other resources? American Naturalist 129:897-906.

Reekie, E. G., and F. A. Bazzaz. 1987c. Reproductive effort in plants. 3. Effect of reproduction on vegetative activity. American Naturalist 129:907-919.

Reznick, D. 1985. Costs of reproduction: an evaluation of the empirical evidence. Oikos 44:257-267.

Richards, J. H., and M. M. Caldwell. 1985. Soluble carbohydrates, concurrent photosynthesis and efficiency in regrowth following defoliation: a field study with Agropyron species. Journal of Applied Ecology 22:907-920.
Ryle, G. J. A., and C. E. Powell. 1975. Defoliation and regrowth in the graminaceous plant: the role of current assimilate. Annals of Botany 39:297-310.

Sakai, A. K., and T. A. Burris. 1985. Growth in male and female aspen clones: a 25 year longitudinal study. Ecology 66:1921-1927.

Samson, D. A., and K. S. Werk. 1986. Size-dependent effects in the analysis of reproductive effort in plants. American Naturalist 127:667-680.

SAS. 1985. SAS user's guide: statistics. Version 5 edition. SAS Institute, Cary, North Carolina, USA.

Smith, D. 1975. Trends of nonstructural carbohydrates in the stem bases of switchgrass. Journal of Range Management 28:389-391.

Smith, D., G. M. Paulsen, and C. A. Raguse. 1964. Extraction of total available carbohydrates from grass and legume tissue. Plant Physiology 39:960-962.

Snedecor, G. W., and W. G. Cochran. 1980. Statistical methods. Seventh edition. Iowa State University Press, Ames, Iowa, USA.

Snow, A. A., and D. F. Whigham. 1989. Costs of flower and fruit production in Tipularia discolor (Orchidaceae). Ecology 70:1286-1293.

Sohn, J. J., and D. Policansky. 1977. The costs of reproduction in the mayapple Podophyllum peltatum (Berberidaceae). Ecology 58:1366-1374.

Sokal, R. R., and F. J. Rohlf. 1981. Biometry: the principles and practice of statistics in biological research. Second edition. W. H. Freeman, New York, New York, USA.

Thompson, K., and A. J. A. Stewart. 1981. The measurement and meaning of reproductive effort in plants. American Naturalist 117:205-211.

Tissue, D. T., and P. S. Nobel. 1990. Carbon relations of flowering in a semelparous clonal desert perennial. Ecology 71:273-281.

Tortensson, P., and A. Telenius. 1986. Consequences of differential utilization of meristems in the annual Spergularia marina and the perennial $S$. media. Holarctic Ecology 9:20-26.

Watson, M. A. 1984. Developmental constraints: effect on population growth and patterns of resource allocation in a clonal plant. American Naturalist 123:41 1-426.

Watson, M. A., and B. B. Casper. 1984. Morphogenetic constraints on patterns of carbon distribution in plants. Annual Review of Ecology and Systematics 15:233-258.

Weiner, J. 1988. The influence of competition on plant reproduction. Pages 228-245 in J. Lovett Doust and L. Lovett Doust, editors. Plant reproductive ecology: patterns and strategies. Oxford University Press, Oxford, England.

Williams, R. D. 1964. Assimilation and translocation in grasses. Annals of the Botanical Society of London (New series) 28:419-425.

Wolf, D. D. 1978. Nonstructural carbohydrate and dry matter relationships in alfalfa tap roots. Crop Science 18:690692. 